Ahlholm, M., I. Piippo \& P. Portaankorva-Koivisto (toim.) 2021. Koulun monet kielet. Plurilingualism in the school. AFinLA-e. Soveltavan kielitieteen tutkimuksia 2021 / n:0 13. 141-165.

Noora Helkiö

Aalto-yliopisto

\title{
Kehollinen toiminta opetuskeskustelun tukena valmistavassa opetuksessa
}

This article examines bodily action as an interactional resource in instruction preparing for basic education. Using conversation analysis as method, the study seeks to answer two research questions: How does bodily action support and enable participation in the classroom interaction, and how do the teacher and the students use it in IRE/IRF-sequences? The first focus is on how the teacher uses bodily action when asking questions from the students. Secondly, the study focuses on how the teacher verbalizes students' bodily action into verbal utterances. The writer argues that bodily action can enable participation in the classroom interaction as well as language teaching and language learning. For the teacher it serves as a pedagogical tool and for the student as a means of participation when learning a new language.

Keywords: embodiment, classroom interaction, educational dialogue, preparatory instruction

Asiasanat: kehollisuus, luokkahuonevuorovaikutus, opetuskeskustelu, valmistava opetus 


\section{Johdanto}

Perusopetukseen valmistava opetus on suunnattu suomea toisena kielenä puhuville maahanmuuttajataustaisille oppilaille, joiden taidot eivät ole vielä riittäviä perusopetuksen ryhmässä opiskeluun. Valmistavan luokan tavoitteena on vahvistaa suomen kielen taitoja ja perustaitoja, jotka mahdollistavat osallistumisen perusopetukseen. (OPH 2015: 5.) Opettajan tehtävänä on löytää keinot valmistavan opetuksen päämäärien saavuttamiseksi: siihen, miten edistetään ainesisältöjen ja suomen kielen oppimista sekä yhteisymmärryksen saavuttamista rinta rinnan.

Tässä artikkelissa tarkastelen valmistavan opetuksen ryhmässä opetuskeskustelun tukena esiintyvää kehollista toimintaa, erityisesti käsieleitä ja pään liikkeitä. Pyrin selvittämään, millä tavoin suomea äidinkielenä puhuva opettaja ja suomea toisena kielenä puhuvat oppilaat hyödyntävät eleitä vuorovaikutuksessa: mielenkiinnon kohteena on erityisesti se, miten kehollinen toiminta tukee vuorovaikutusta ja opetuskeskustelua luokkahuoneessa ja edesauttaa vuorovaikutukseen osallistumista. Vuorovaikutustilanteet, joita artikkelissani analysoin, ovat institutionaalisuuden ja pedagogisten tavoitteiden ohjaamia, ja sen lisäksi ne ovat kielellisesti epäsymmetrisiä, eli niissä puhujien suomen kielen taito vaihtelee.

Analyysini keskeisenä lähtökohtana ovat opettajan esittämät kysymykset osana kolmiosaista opetussykliä. Keskityn ensiksi tarkastelemaan sitä, miten opettaja käyttää kehollista toimintaa kysymystensä tukena. Toiseksi tarkastelen sitä, miten oppilaat käyttävät kehollista toimintaa vastatessaan ja miten opettaja sanallistaa tätä toimintaa. Keskeisenä tarkastelun kohteena ovat siis eleet ja niiden linkittyminen sanallisiin ilmauksiin. Aineisto on kerätty alakoulun valmistavalta luokalta.

Artikkelin teoreettisen ja metodologisen viitekehyksen muodostaa multimodaalinen keskustelunanalyysi: aitojen vuorovaikutustilanteiden kautta pyrin kuvaamaan keinoja, joilla vuorovaikutuksen osallistujat toimivat yhdessä ja tekevät toimintaansa toisille tunnistettavaksi (ks. esim. Lindholm ym. 2016). Tästä viitekehyksestä voidaan tarkastella kaikkia vuorovaikutuksen modaliteetteja, kuten kehollista toimintaa, fyysistä ympäristöä ja puhetta, joita ihmiset hyödyntävät vuorovaikutuksessa toisten ihmisten kanssa ja joiden avulla vuorovaikutuksen osallistujat ymmärtävät toisiaan ja tulevat ymmärretyiksi (ks. esim. Kääntä \& Haddington 2011: 11-12). Käsitteellä kehollinen toiminta tarkoitan kaikkia niitä vuorovaikutuksellisia toimintoja, jotka vuorovaikutuksen osallistujat tuottavat kehonosan tai liikkeen, kuten katseen suuntaamisen, avulla. Esimerkeissäni opettajan kehollinen toiminta on aina jokin käsiele, mutta oppilaiden kehollinen toiminta on kokonaisvaltaisempaa.

Artikkelini rakentuu seuraavasti: Luvussa 2 esittelen aineiston sekä tarkemmin edellä esitellyn tutkimusmenetelmän. Luvussa 3 kartoitan tutkimukseni kannalta keskeisintä taustaa ja tärkeimpiä käsitteitä. Luku 4 muodostaa artikkelini ytimen eli analyysiosan. Luvussa 5 tiivistän analyysini tulokset ja pohdin tekemiäni päätelmiä. 


\section{Tutkimusmenetelmä ja aineisto}

\subsection{Multimodaalinen keskustelunanalyysi}

Tämän artikkelin tutkimusmenetelmänä on multimodaalinen keskustelunanalyysi. Lingvistisen keskustelunanalyysin juuret ovat etnometodologiassa, jossa havainnoimalla tutkitaan arkielämän toimintoja (Heritage 1996 [1984]). Keskustelunanalyysin (engl. conversation analysis, CA) tutkimuskohteena on ihmisten välinen sosiaalinen toiminta. Empiirisenä ja deskriptiivisenä metodina se pyrkii kuvaamaan, miten vuorovaikutuksen osallistujat toimivat yhdessä ja tekevät toimintaansa toisille tunnistettavaksi. Menetelmän tarkoitus ei ole arvottaa vuorovaikutusta vaan kuvata sitä mahdollisimman hienosyisesti. (Ks. esim. Lindholm ym. 2016; Hoey \& Kendrick 2018.) Keskustelunanalyysi tarkastelee monenlaisia sosiaalisen vuorovaikutuksen resursseja: esimerkiksi puhetta, kehollisuutta, liikettä ja teknologiaa.

Vuorovaikutuksen multimodaalisuuden tutkimus on muotoutunut merkittäväksi tutkimuskohteeksi useilla eri aloilla viime vuosikymmenien aikana. Eleillä, katseilla ja muulla kehollisella toiminnalla ihmiset tuottavat monenlaista sosiaalista toimintaa, kuten ilmaisevat yhteisymmärrystä (Sorjonen 2010) tai osoittavat orientoitumista meneillään olevaan tilanteeseen (Seyfeddinipur \& Gullberg 2014: 1). Kehollisilla toiminnoilla voidaan myös paikata ongelmia puheena tuotetuissa ilmaisuissa, korostaa puheena tuotettua ilmaisua tai ilmaista asioita, joita ei ole helppo esittää puheessa (Gullberg 2008).

Keskustelunanalyyttinen ja etnometodologinen viitekehys nykytutkimuksessa tarkastelee kehollista toimintaa ja puhetta samanarvoisina modaliteetteina, jotka eivät ole toisistaan erillisiä, vaan vuorovaikutuksessa toistensa kanssa luonnollisessa, keskinäisessä suhteessa (ks. esim. Kendon 1980; McNeill 1992; Eskildsen \& Wagner 2015; Goodwin 2017). Vuorovaikutus ymmärretään sosiaalisena toimintana, jonka osallistujat hyödyntävät monenlaisia vuorovaikutuksen resursseja tehdessään toimintaansa ymmärrettäväksi muille (Seedhouse 2004).

Analysoin artikkelissani erityisesti vuorovaikutuksen osallistujien tuottamia eleitä. Eleet ovat yhtä olennainen osa vuorovaikutusta kuin vaikkapa sanat ja lauseet, ja ne liittyvät kiinteästi puheen tuottamisen prosessiin (McNeill 1992: 2). Eleitä voidaan tarkastella niin ikään näkyvänä toimintana (engl. visible action as gesture) silloin, kun niitä käytetään lausumana tai osana lausumaa. Lausuma määritellään tässä kontekstissa minä tahansa kommunikatiivisena toimintana, jonka pyrkimyksenä on välittää informaatiota. (Kendon 2004: 7.) Eleiden tutkimus osana puheen tuottamista ja vuorovaikutusta liittyy keskustelunanalyysin perusperiaatteisiin - siihen, miten osallistujat yhteisesti neuvottelevat meneillään olevasta sosiaalisesta toiminnasta ja rakentavat keskinäistä yhteisymmärrystä. 


\subsection{Aineisto}

Artikkelini aineisto on videoitu luokkahuonekorpus, joka on kerätty oppilaiden suomen kielen kehittymistä alakoulun valmistavalla luokalla tutkivaan Long Second -hankkeeseen. Hankkeen on rahoittanut Koneen säätiö, ja sen ovat toteuttaneet Helsingin yliopisto ja Tallinna Ülikool vuosina 2011-2016. Vaikka varsinainen hanke on jo päättynyt, aineistokorpus on edelleen tutkijoiden käytössä. Korpuksen vuorovaikutustilanteiden erityispiirteitä ovat olleet muun muassa monikielisyys (ks. esim. Ahlholm 2016; Yli-Piipari tässä teoksessa), multimodaalisuus (ks. esim. Helkiö 2019; Routarinne \& Ahlholm 2021) sekä erilaiset osallistumisen keinot monenkeskisessä, uutta kieltä oppivien luokkavuorovaikutuksessa (ks. esim. Gustafsson 2014).

Aineistoa kuvattiin yhden lukuvuoden ajan kaksi kertaa viikossa suomalaisen alakoulun valmistavalla luokalla. Tähän artikkeliin valittu osa aineistosta koostuu kahdesta 45 minuutin pituisesta oppitunnista, jotka on kuvattu kevätlukukauden alussa. Analysoimillani oppitunneilla aiheena on biologia ja ihmisen kehon toiminta. Opiskeltava teema liittyy siten suoraan tässä artikkelissa tarkasteltavaan keholliseen toimintaan vuorovaikutuksessa. Kun opetuksen kohteena ovat ruumiintoiminnot, omaa ja toisten fyysistä olemusta voidaan käyttää havainnointivälineenä, mikä tuottaa vuorovaikutustilanteeseen enemmän kohdennettua kehollisuutta.

Aineistonkeruussa on huolehdittu tarkasti tutkimusetiikasta ja osallistujien informoinnista: Helsingin kaupungin opetusvirastolta ja videoissa esiintyvien oppilaiden vanhemmilta sekä oppilailta itseltään on saatu lupa nauhoitusta ja sen tutkimuskäyttöä varten. Aineistossa esiintyvät opettaja, koulunkäynninohjaajat ja oppilaat on aineistoesimerkeissä nimetty pseudonyymein.

Analysoimillani oppitunneilla paikalla olevien oppilaiden äidinkielet ovat viro ja venäjä, mutta aineistossa esiintyy myös kurdin-, makedonian-, latvian- ja portugalinkielisiä lapsia. Oppitunneilla, joita analysoin, paikalla olevista oppilaista Eetun (12), Eimarin (12) ja Ebban (11) äidinkieli on viro. Rolanin (11) ja Radimirin (7) äidinkieli on venäjä. Lasten nimien perässä suluissa ovat oppilaiden iät, koska valmistavalla luokalla oppilaat voivat olla eri-ikäisiä.

Oppitunneilla, joita analyysissani tarkastelen, oppilaat istuvat pienryhmänä samassa pöydässä, jonka ääressä he tekevät erilaisia tehtäviä. Opettaja yleensä seisoo pöydän äärellä ja paikoin liikkuu sen ympärillä. Tunnit alkavat tavallisesti siten, että opettaja esittää oppilaille kysymyksiä oppitunnin aiheesta. Tämän jälkeen opettaja usein antaa oppilaille tehtävän, jota oppilaat alkavat tehdä.

Analyysilukujeni esimerkkikatkelmissa kehollinen toiminta ja puhe linkittyvät läheisesti toisiinsa, minkä takia olen valinnut kaksi erilaista tapaa korostaa litteraateissa sekä puhetta että kehollista toimintaa. Analyysin kannalta keskeisimmät puhutut jaksot on lihavoitu, oleellisin kehollinen toiminta on merkitty korostusvärillä ja kehollinen toiminta on lisäksi merkitty \{-merkillä ja kapiteelikirjaimilla. Osassa esimerkkejä on lisäksi piirroskuva, joka havainnollistaa analyysin kohteena olevaa 
toimintaa. Lähtökohtana on ollut mahdollisimman yksinkertainen, helposti luettava ja ymmärrettävä litterointitapa.

\section{Tutkimuksen taustaa ja käsitteitä}

\subsection{Opetuskeskustelun jäsentäminen luokkahuoneessa: kolmiosainen opetussykli}

Luokkahuoneessa tapahtuvaa vuorovaikutusta ohjaavat tietyt institutionaalisuuden asettamat rakenteet ja roolit sekä normatiivisuus (ks. esim. Tainio 2007). Yksinkertaistettu asetelma on monelle tuttu: opettajan institutionaalisena tehtävänä on opettaa ja oppilaan tehtävänä on toteuttaa oppimista tavoittelevaa toimintaa opettajan avustuksella. Institutionaalisessa vuorovaikutuksessa osallistujat suorittavat tietynlaisia institutionaalisia tehtäviä sen pohjalta, miten he tulkitsevat ja ymmärtävät tilanteen ja oman osallistujuutensa suhteessa instituutioon (Peräkylä 1997: 177; ks. myös Raevaara 2016: 153), vaikkakaan suhde arkikeskusteluun ei ole täysin yksiselitteinen (Heritage 2005; ks. myös Lindholm ym. 2016: 12).

Tämän artikkelin analyysiosassa keskeisenä lähtökohtana on kolmiosainen opetussykli, joka on konventionaalistunut tapa jäsentää opetuskeskustelua luokkahuoneessa. Opetussykli muodostuu opettajan aloitteesta, oppilaan tuottamasta responssista eli vastauksesta ja oppilaan vastauksen evaluoinnista eli arvioinnista, jonka opettaja tuottaa. Sen esittelivät ensimmäisen kerran Sinclair ja Coulthard (1975) diskurssianalyyttisessa tutkimuksessaan, jossa he tarkastelivat vuorovaikutuksen rakentumista luokkahuoneessa (ks. myös Seedhouse 2004). Kansainvälisessä tutkimuksessa kolmiosaista opetussykliä nimitetään joko IRE- tai IRF-sykliksi (engl. initiative-response-evaluate/feedback).

Opetussyklin ensimmäinen vuoro on opettajan esittämä kysymys. Kysymyksillä opettaja voi testata oppilaiden osaamista ja selvittää, mitä he osaavat. (Ks. esim. Keravuori 1988; Tainio 2007: 41.) Kysymykset ovat opettajalle tärkeä vuorovaikutuksellinen keino (Kleemola 2007: 63). Opetussyklin toisen position ottaa oppilas, joka tuottaa vastausvuoron opettajan esittämään kysymykseen. Kolmannen position ottaa taas opettaja. Tässä opetussyklin sulkevassa vuorossa opettaja arvioi oppilaan vastauksen tai antaa siitä palautetta. (Seedhouse 2004; Tainio 2007; Heinonen 2017.)

Näin esitettynä opetussykli toteutuu vain silloin, kun sekvenssi on ongelmaton, eli kysymys ja vastaus ovat onnistuneita (Kleemola 2007: 63). Kolmiosaisen opetussyklin vuorojen välille voi muodostua välisekvenssejä, jolloin toisen position vastausvuoro tai kolmannen position evaluoiva vuoro eivät välittömästi seuraa edeltävää vuoroa (Kleemola 2007; Karvonen 2007). Välisekvenssi voi syntyä esimerkiksi silloin, jos opettaja pyytää tarkentavan vastauksen oppilaalta (Kleemola 2007: 63). 
Myös viittaaminen ja vastausluvan saaminen voivat synnyttää välisekvenssin, jos useampi oppilas haluaa vastata opettajan esittämään kysymykseen (Karvonen 2007: 121-122).

On myös huomioitava, että luokkahuoneessa vuorovaikutus jakautuu usein rinnakkaisiksi ja limittäisiksi keskusteluiksi (Jones \& Thornborrow 2004), eikä suinkaan jäsenny pelkästään edellä mainitun opetussyklin mukaisesti. Keskustelut voivat liittyä niin oppitunnin agendaan kuin sen ulkopuolisiin aiheisiin (ks. esim. Markee 2005; Lehtimaja 2012: 174-211). Kolmiosainen opetussykli on myös perinteisesti opettajajohtoinen: voi olla aiheellista tarkastella, millä tavoin se sopii osaksi nykymuotoisten oppimisympäristöjen ja työtapojen tarkastelua. Konventionaalistuneena perusrakenteena se kuitenkin tarjoaa yhdenlaisen keskustelunanalyyttisen työkalun analysoida vuorovaikutusta luokkahuoneessa.

\subsection{Kielenoppijoiden luokkahuonevuorovaikutus}

Tutkimus uutta kieltä oppivien vuorovaikutuksesta on viime vuosina ollut aktiivista (ks. esim. Markee 2015; Sert 2015; Filipi \& Markee 2018). Kielenoppimista tarkastellaan erityisesti sosiaalisena, vuorovaikutuksen osallistujien välisenä toimintana (ks. esim. Pallotti \& Wagner 2011). Suomalaisessa tutkimuksessa esille ovat nousseet luokan ulkopuoliset kontekstit (Kurhila \& Lehtimaja 2019; Lilja \& Piirainen-Marsh 2019; Savijärvi 2019). Suomen kieltä oppivien vuorovaikutusta valmistavassa opetuksessa on myös tutkittu lisääntyvissä määrin. Aiheesta on syntynyt useita opinnäytetöitä (ks. esim. Ahlholm \& Lankinen 2021), ja kielen rakenteiden karttumista vuorovaikutuksessa on tutkittu esimerkiksi multimodaalisten pyyntörakenteiden (Routarinne \& Ahlholm 2021) sekä omistuslauseen ja negaation (Yli-Piipari tässä teoksessa) kautta.

Luokkahuonevuorovaikutuksessa opettajan oppilaille mallintama kieli on niin oppimisen kohde kuin oppimisen väline. Kielenoppimiseen luokkahuoneessa vaikuttavat opettajan pedagogiset valinnat sekä se, millä tavoin vuorovaikutus luokkahuoneessa rakentuu. Keskeistä on myös oppilaiden tuotosten evaluointi kielenoppimisen ja -opettamisen näkökulmasta: opettaja voi evaluoida oppilaan tuotoksessa esimerkiksi sekä semanttista sisältöä että sen syntaktista rakennetta ja muotoa. (Seedhouse 2004: 183-187.)

Kielenoppimista luokkahuoneessa voidaan lähestyä myös luokkahuonevuorovaikutuskompetenssin (engl. classroom interaction competence, CIC) näkökulmasta, joka tarkoittaa opettajan ja oppilaiden mahdollisuutta käyttää vuorovaikutusta kielen oppimista edistävänä ja merkityksiä välittävänä resurssina. Tällaiseen kompetenssiin kuuluu keskeisesti se, millaista kieltä opettaja ja oppilaat käyttävät luokkahuoneessa. Vuorovaikutuksen osallistujat käyttävät kieltä luokkahuoneessa niin, että he muokkaavat sitä vastaanottajalle sopivaksi. Heillä on myös eri keinoin mahdollisuuksia luoda vuorovaikutuksellista tilaa meneillään olevaan tilanteeseen. (Walsh 2011.) Lisäksi monenlaisen vuorovaikutuksen voidaan ajatella palvelevan 
luokkahuoneen keskeistä tavoitetta eli kielenoppimista riippumatta siitä, liittyykö se tiukasti oppitunnin agendaan ja tavoitteisiin (vrt. Seedhouse 2004).

Huomionarvoista on osaltaan myös se, että institutionaalisessa vuorovaikutuksessa, jossa on mukana sekä äidinkielisiä puhujia että kielenoppijoita, vallitsee kahtalainen epäsymmetria. Ensinnäkin koulu ympäristönä leimaa osallistujien institutionaalisia rooleja (ks. esim. Tainio 2007). Toiseksi äidinkielinen vuorovaikutuksen osallistuja on asiantuntija suhteessa kieleen (ks. Kurhila 2001).

\subsection{Kehollinen toiminta luokkahuoneessa}

Toisen kielen oppimisen tutkimus on vanhastaan painottunut verbaalin kielen tutkimukseen, vaikka kehollisuuden suuri merkitys vuorovaikutuksessa tunnetaan (ks. esim. Seo 2011; Sert 2015; Tai \& Khabbazhashi 2019). Myös opettajan kehollista toimintaa luokkahuonevuorovaikutuksessa on tutkittu viime vuosina yhä aktiivisemmin (ks. esim. Tai \& Brandt 2018; Kääntä 2021).

Toisen kielen opettajien eleitä sanallisissa selityksissä tutkinut Lazaraton (2004) on todennut, että sanan selittäminen eleellä vähentää puheena tuotetun selittämisen tarvetta. Tällainen toiminta ei kuitenkaan osoita opettajan pedagogista tai vuorovaikutustaitojen puutetta vaan ennemminkin opettajan pedagogisen osaamisen laajuutta. (Lazaraton 2004: 100.) Eleet ovat keskeinen osa opettajan pedagogisten keinojen valikoimaa (ks. myös Taleghani-Nikazm 2008). Kehollinen toiminta, jolla opettaja pyrkii auttamaan oppilaitaan, saa herkästi oppilaiden huomion ja tekee oppitunnista dynaamisen (Tellier 2010: 2, ks. myös Tai \& Brandt 2018).

Kielten opettajat voivat käyttää eleitä myös kommunikatiivisena strategiana, jonka avulla he antavat oppilaille vihjeitä uusien tai hankalien sanojen merkityksistä. Tällä tavoin opettaja antaa oppilaille mahdollisuuden tuottaa sanan sen sijaan, että opettaja tuottaisi sen suoraan itse. Eleillä on näin myös kielen oppimista mahdollistava ja helpottava merkitys. (Taleghani-Nikazm 2008.) Lisäksi ne tarjoavat tehokkaan ja tärkeän pedagogisen työvälineen opettajalle myös esimerkiksi silloin, kun opettaja selittää jotakin oppilaille. Eleiden avulla opettaja voi selittää sanojen kontekstuaalisesti asianmukaisen merkityksen ja näin edesauttaa oppilaiden ymmärtämistä. (Ks. esim. Tai \& Brandt 2018; Tai \& Khabbazhashi 2019.)

Opettajan eleet ja muut keholliset toiminnot eivät myöskään ole sattumanvaraisia, vaan ne jäsentävät vuorovaikutusta luokkahuoneessa, ja niihin myös suuntaudutaan sellaisina (Kääntä 2011). Esimerkiksi pelkkä katse tai nyökkäys voi riittää merkitsemään puhujanvaihdoksen tai identifioimaan seuraavan puhujan (mts. 134135). Suuntaamalla huomion tiettyyn ihmiseen tai huomionkohteeseen vuorovaikutuksen osallistujilla on mahdollisuus koordinoida keskeisiä toimintoja vuorovaikutuksessa (Ruusuvuori 2016: 48-49).

Oleellista on myös se, että opettaja ja oppilas jakavat saman fyysisen tilan (Kääntä 2011; ks. myös Mortensen 2008). Jaettu fyysinen tila on kehollisen vuoro- 
vaikutuksen ideaali ympäristö: keholliset viestit ovat tilanteisia ja niiden merkitys välittyy ja täsmentyy näköhavainnon kautta (Kääntä 2011: 147). Kun vuorovaikutuksen osallistujat jakavat saman tilan, vuorovaikutuksen eri resursseja voidaan käyttää samanaikaisesti ja limittäin, mikä edesauttaa yhteisymmärryksen saavuttamista.

\section{$4 \quad$ Aineiston analyysi}

Artikkelini ytimen muodostavassa analyysiluvussa tarkastelen seitsemää esimerkkikatkelmaa. Analyysiluku on jaettu kahteen osaan, joista ensimmäisessä tarkastelen sitä, miten opettaja täydentää oppilaille esittämiään kysymyksiä kehollisella toiminnalla. Toisessa osassa tarkastelen, miten opettaja sanallistaa oppilaiden kehollisesti tuottamia vastausvuoroja. Katkelmat havainnollistavat tutkimukseni kannalta keskeisimpiä asioita: kehollista toimintaa vuorovaikutuksen tukena ja siihen osallistumisen keinona.

\subsection{Opettaja täydentää kysymystä kehollisella toiminnalla}

Esimerkki 1 on oppitunnilta, jonka aiheena on ihmisen sydämen toiminta. Katkelma on oppitunnin alusta. Opettaja on esittänyt oppilaille oppitunnin aiheeseen liittyviä kysymyksiä.

(1) Kun sinä nukut.

01 EET yksi kerta ku mä pieni ni tekee,

\{KATSOO OPETTAJAA

02 \{OPETTAJA KÄÄNTYY KATSOMAAN EETUA

03 tyk tyky tyk tyk tyky tyk,

\{NOSTAA VASEMMAN KÄDEN RINTANSA PÄÄLLE JA LIIKUTTAA

KÄTTÄ EDESTAKAISIN

04 OPE nii (.) nii (.) kun sinä n[ukut-

\{KÄÄNTYY KATSOMAAN MUITA OPPILAITA, NOSTAA KÄDET

YHTEEN JA NOJAA PÄÄNSÄ NIIHIN

05 RAD

06 OPE kun- [kun sinä nukut (.) niin kuuletko sinä kun

07 sydän lyö,

08 EET [-- tyk tyky tyk tyk tyk tyk

\{ALKAA UUDESTAAN LIIKUTTAA KÄTTÄ RINTANSA PÄÄLLÄ

09 EBB joo.

10 OPE £joskus kuuluu joo.£

\{LASKEE KÄDET ALAS JA KÄVELEE POIS PÖYDÄN LUOTA. 
11 EET it go like everywhere-

12 OPE no niin.

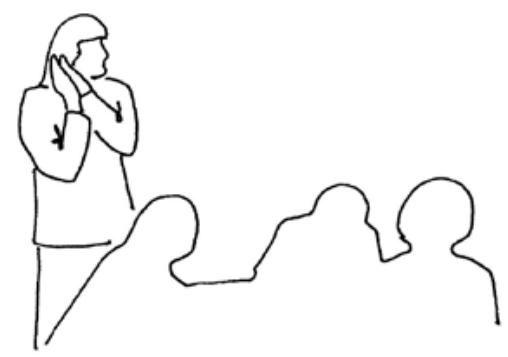

Piirroskuva 1

Esimerkin alussa oppilaista Eetu alkaa kertoa tunnin aiheeseen liittyvästä omakohtaisesta kokemuksesta (r. 01). Hän aloittaa vuoronsa temporaalisella ilmaisulla, mikä tässä orientoi vastaanottajan tulossa olevaan toimintaan eli menneestä tapahtuneesta kertomiseen (vuoron alusta ks. ISK 2004: § 1025-1036): yksi kerta ku mä pieni ni tekee. Seuraavaksi hän nostaa vasemman kätensä rintansa päälle, alkaa liikuttaa sitä edestakaisin ja elehtii tällä tavoin, kuinka sydän sykkii. Ele on ikoninen ja sanallisen ilmauksen korvaava. Tällaiset ikoniset eleet jäljittelevät puhetta ja linkittyvät läheisesti sen semanttiseen sisältöön (eleiden luokittelusta ks. McNeill 1992). Eetu jatkaa vuoroaan onomatopoeettisella, sydämen sykkimistä jäljittelevällä interjektioketjulla: tyk tyky tyky tyk tyk tyky tyk (r. 03).

Opettaja vastaanottaa Eetun vuoron kahdentuneella dialogipartikkelilla nii nii (r. 04). Dialogipartikkelilla hän sekä osoittaa samanmielisyyttä Eetun kanssa että hyväksyy tämän oma-aloitteisen vuoron osaksi vuorovaikutuksen kulkua (partikkelivuoroista ks. esim. ISK 2004: § 1044). Opettaja voi hyväksyä tällaiset luokkahuoneen vuorottelusysteemiä rikkovat oma-aloitteiset vuorot, jos ne ovat oppitunnin agendaa palvelevia (Tainio 2005). Luokkahuoneessa monenlaiset tilanteet tarjoavat mahdollisuuden oppia kieltä (ks. Lehtimaja 2012: 217-219), mikä voi osaltaan vaikuttaa siihen, että opettaja hyväksyy Eetun vuoron. Seuraavaksi opettaja aloittaa kysymyksen kun sinä nukut- (r. 04), nostaa kätensä yhteen ja nojaa päänsä niihin. Tällä kehollisella toiminnalla opettaja elehtii nukkumista ja toisintaa sillä sanallisen ilmauksen merkityksen, mikä voi auttaa oppilaita kysymyksen ymmärtämisessä.

Kun oppilaista Radimir pyrkii sanomaan jotain (r. 05), opettajan kysymys keskeytyy (r. 04). Opettaja aloittaa vuoronsa uudestaan (r. 06), mutta vuoro keskeytyy taas, kun Eetu jatkaa sydämen sykkimisen jäljittelyä puheen ja eleen avulla. Opettaja 
toistaa konjunktion kun uudestaan ja vasta sitten saa jatkettua kysymyksensä loppuun kun sinä nukut niin kuuletko sinä kun sydän lyö (r. 06-07). Vaikka opettaja joutuu aloittamaan kysymyksensä uudelleen, hän tuottaa kysymykseen liittyvän kehollisen toiminnan jo rivin 04 vuoronsa aikana. Ele päättyy vasta, kun hän tuottaa opetussyklin kolmannen position vuoron (r. 10) Ebban vastauksen (r. 09) jälkeen. Tämän jälkeen opettaja siirtyy pois oppilaiden pöydän luota ja vie partikkelivuorolla no niin (r. 12) oppilaat seuraavaan aiheeseen.

Opettajan kysymys muodostuu puheena tuotetusta ilmaisusta ja eleestä (ks. piirroskuva 1). Opettaja myös sanallistaa Eetun eleen lyödä-verbillä ja asettaa sen tiettyyn kontekstiin, jossa sydämen sykkimistä voi kuulla (r. 06-07). Hän mahdollisesti tulkitsee, ettei Eetu tiedä tätä kuvaavaa verbiä, koska Eetu korvaa sanan sitä jäljittelevällä ääntelyllä. Opettajan vuorolla on tässä katkelmassa monia funktioita: hän hyödyntää siinä sekä omaa kehollista toimintaansa että oppilaan kehollista toimintaa ja näiden kautta asteittain syntyvää yhteisymmärrystä. Eleiden linkittäminen kysymyksen semanttiseen sisältöön voi edesauttaa kysymyksen ymmärtämistä ja osaltaan tarjota useammalle oppilaalle vastausmahdollisuuden kielitaidosta huolimatta.

Seuraavassa esimerkissä aiheena on edelleen sydämen toiminta. Opettaja ja oppilaat ovat juuri laskeneet, kuinka monta kertaa minuutissa oma sydän lyö.

(2) Sydän lyö hitaasti.

01 OPE aika monella oli seitsemänkymmentä,

02 kahdeksankymmentä yhdeksänkymmentä=milloin sydän

03 lyö oikein hitaasti?

\{NOSTAA KÄTENSÄ RINTANSA PÄÄLLE JA LIIKUTTAA SITÄ HITAASTI EDESTAKAISIN

04 EET kun sä n[uk-

05 \{EETU JA EIMAR KATSOVAT OPETTAJAA

06 EIM [silloin kun kuo[LEE,

07 \{OPETTAJA NYÖKYTTÄÄ PÄÄTÄNSÄ JA SIIRTÄÄ KATSETTAAN

08 EETUSTA EIMARIIN

09 EET [kun sä nukkut-

10 EIM kuolemine aik[a-

11 EET [kun sä nuk-

12 OPE kun kuolee ei lyö ollenkaan kun nukkuu lyö. \{SIIRTÄÄ KÄDEN POIS RINNALTAAN

Opettaja toteaa esimerkin alussa, kuinka monta kertaa minuutissa useimpien oppilaiden sydän löi (r. 01-02). Hän kiirehtii ilman taukoa kysymykseen milloin sydän lyö oikein hitaasti (r. 02-03). Samanaikaisesti hän nostaa kätensä rintansa päälle, lii- 
kuttaa kättä siinä hitaasti edestakaisin ja tuottaa ikonisena eleenä, kuinka sydän lyö. Kysymyksen semanttinen sisältö liittyy erityisesti sydämen lyömisen tahtiin. Ele tarkentaa puheen sisältöä (ks. Stivers \& Sidnell 2005) ja tukee sanallista ilmausta, mikä voi auttaa oppilaita kysymyksen ymmärtämisessä.

Eetu ja Eimar kilpailevat vastausvuoroista (r. 04 ja 06). Molemmat tuottavat oma-aloitteiset vastausvuorot (r. 04 ja r. 06), jotka he myös toistavat hieman eri tavoin muotoiltuina (r. 09-11). Opettaja hyväksyy molempien vastausvuoron nyökyttelemällä päätänsä ja siirtämällä katseensa vuorotellen Eetusta Eimariin (r. 07-08). Katseen siirrolla hän myös eksplikoi, kummalle yhteen vuoroon sulautetut vastausten tarkennukset on osoitettu (r. 12): kun kuolee ei lyö ollenkaan on suunnattu Eimarille ja kun nukkuu lyö on suunnattu Eetulle. Samaan aikaan opettaja siirtää kätensä pois rintansa päältä ja päättää eleen. Kuten edellisessä esimerkissä, myös tässä kysymykseen liittyvän eleen opettaja päättää vasta, kun oppilas on tuottanut kysymykseen vastauksen. Eleen avulla opettaja jäsentää vuorovaikutusta ja ikään kuin säilyttää kysymystilan avoinna, kunnes joku oppilaista tuottaa siihen hyväksyttävän vastauksen. Opetussyklin opettaja sulkee puheena tuotetulla vuorolla ja laskemalla kätensä alas.

Opetussyklin kolmannen position tutkiminen on keskeinen ikkuna luokkahuonevuorovaikutuksen tutkimukseen: sekventiaalisesti kolmas positio on vuorovaikutuksessa se paikka, jossa oppilaan vastausta arvioimalla opettaja voi joko kannustaa oppilasta tai lannistaa hänet (Tainio 2007: 43). Tässä esimerkissä opettaja hyväksyy Eimarin vastauksen, vaikka korjaakin sitä hieman (r. 12). Katkelmassa kehollisuus ja puhe linkittyvät jälleen läheisesti toisiinsa ja liittyvät erilaisiin toimintoihin vuorovaikutuksessa: niin tilanteiseen osallistumiskehikkoon, oppilaiden vastausten evaluointiin kuin kysymyksen semanttiseen sisältöön.

Kolmannessa esimerkissä opettaja ja oppilaat ovat puhuneet oppitunnin aikana aivoista. Edeltävistä esimerkeistä poiketen tässä opettajan tuottama ele on deiktinen, eli sillä osoitetaan jotakin fyysisessä tai abstraktissa tilassa (McNeill 1992). Ele myös tukee sanallista ilmausta. Eleen funktio on sama kuin edeltävissä esimerkeissä: se auttaa oppilaita ymmärtämään kysymyksen.

(3) Jos päähän sattuu pahasti.

01 OPE mút jos- mutt jos päähän sạttuu pahasti nii mịtä

\{KOSKETTAA PÄÄTÄNSÄ, KATSOO ROLANIA

JA KOSKETTAA ETUSORMELLA ROLANIN KÄSIVARTTA

02 sịtte voi tạpahtua kerro.

(3.5)

04 \{ROLAN TIPAUTTAA PÄÄNSÄ PÖYTÄÄ VASTEN 
05 OPE aina ei kuole,

\{VILKAISEE MUITA OPPILAITA JA KÄÄNTÄÄ KATSEEN

TAKAISIN ROLANIIN

$06 \quad$ RROLAN KATSOO OPETTAJAA

07 EIM hänel- hän ei- hän ei kưole mut hän en jaksa tehdä mịtään,

08

\{OPETTAJA KATSOO EIMARIIN

09 OPE aivan (.) ei jaksa tehdä mịtään, \{NYÖKYTTÄÄ PÄÄTÄNSÄ

Ensin opettaja esittää kysymyksen mut jos päähän sattuu pahasti nii mitä sitte voi tapahtua kerro (r. 01-02). Lausuessaan vuoronosan päähän opettaja koskettaa sormella päätänsä. Samanaikaisesti hän katsoo Rolania ja koskettaa toisen kätensä etusormella tämän käsivartta. Opettaja tarjoaa näin vastausvuoron yksilöidysti Rolanille (vrt. Kääntä 2011). Opettajan vuoroa seuraa pitkä tauko, jonka aikana kukaan muista oppilaista ei ota oma-aloitteisesti vastausvuoroa. Lopulta Rolan tuottaa vastauksen ikonisena ja puhetta korvaavana eleenä (r. 04): hän tipauttaa päänsä pöytään, minkä opettaja kiinnostavasti tulkitsee kuolemisen elehtimiseksi (r. 05). Opettajan vuoro on kolmiosaisen opetussyklin kolmannen position evaluoiva vuoro, jolla hän osittain hyväksyy Rolanin vastauksen mutta merkitsee sen myös hieman riittämättömäksi. Samaan aikaan opettaja suuntaa katseensa hetkeksi muihin oppilaisiin. Tämän voinee tulkita niin, että hän siirtyy yksilöidystä vuoron tarjoamisesta yksilöimättömään vuoron tarjoamiseen, jotta toivotunlainen vastaus kysymykseen voidaan saada.

Eimar ottaa vastausvuoron (r. 07), jolla hän opettajan vuoron osittain toistamalla antaa oman vastauksensa ja samalla huomioi vuorossaan myös Rolanin tuottaman vastauksen: hänel- hän ei- hän ei kuole mut hän en jaksa tehdä mitään. Opettaja hyväksyy Eimarin vastauksen sekä puheena tuotettuna että nyökkäyksellä: aivan ei jaksa tehdä mitään (r. 09). Tässä esimerkissä opettaja merkitsee deiktisellä eleellä ja sanallisella ilmauksella huomionkohteeksi erityisesti pään - ei minkä tahansa kehonosan, jota voi sattua. Ele ja puhe myös linkittyvät jälleen toisiinsa.

Kiehtovaa on se, miten Rolan vastaa opettajan kysymykseen sanallisen ilmauksen korvaavalla eleellä (r. 4) ja miten opettaja suhtautuu siihen. Opettajan evaluoiva vuoro (r. 5) implikoi, että opettaja hyväksyy Rolanin eleenä tuotetun vastauksen, vaikka sanallinen ilmaus uupuukin. Sanallisen ilmauksen korvaava ele voi antaa oppilaalle sekä mahdollisuuden osallistua vuorovaikutukseen että tilaisuuden oppia kieltä, kun opettaja sanallistaa oppilaan eleen.

Ensimmäisen analyysiluvun viimeisenä esimerkkinä analysoin katkelmaa, jossa opettaja tuottaa kehollisella toiminnalla vihjeen vastauksesta ennen kuin hän on esittänyt kysymyksen oppilaille. 
(4) Punainen aine.

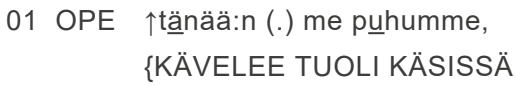

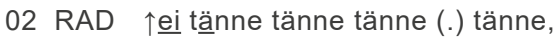
\{NOSTAA VASEMMAN KÄTENSÄ YLÖS, KUROTTAA KOHTI TUOLIA JA KOSKETTAA SITÄ

\{OPETTAJA LASKEE TUOLIN ALAS TOISEN PÖYDÄN VIEREEN

03 OPE punaisesta aineesta jota teissä on.

\section{\{LIIKUTTAA KÄSIÄÄN YLHÄÄLTÄ ALAS YLÄVARTALONSA EDESSÄ JA KÄVELEE TAKAISIN OPPILAIDEN LUO}

04 OPE mịkä se [o-

05 EET [ㄹeri::

06 OPE veri $(0.3)>$ joo $<$ veri.

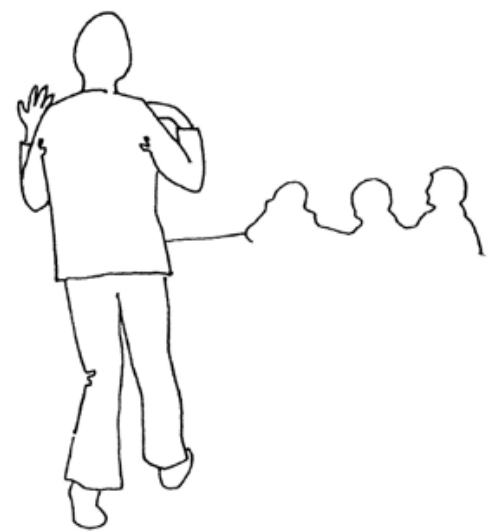

Piirroskuva 2

Aluksi opettaja kertoo, mitä tulevalla oppitunnilla opiskellaan (r. 01). Samalla hän liikkuu luokassa tuoli kädessä, mihin oppilaista Radimir kiinnittää huomiota (r. 02). Kun opettaja on laskenut tuolin alas, hän jatkaa vuoroaan: punaisesta aineesta jota teissä on (r. 03). Samalla opettaja liikuttaa käsiään kehonsa edessä ylhäältä alas ja kävelee takaisin pöytään, jonka ääressä oppilaat istuvat (ks. piirroskuva 2). Seuraavaksi opettaja esittää kysymyksen mikä se o- (r. 04), johon Eetu vastaa osittain päällekkäin opettajan vuoron lopun kanssa (r. 05). Eetun tuottama vastaus on oikea, ja opettaja hyväksyy sen kolmiosaisen opetussyklin kolmannen position vuorolla toistamalla sanan kaksi kertaa sekä tuottamalla hyväksyvän dialogipartikkelin joo (r. 06).

Esimerkki valaisee sitä, kuinka opettaja ohjaa oppilaat huomaamaan hänen kehollisen toimintansa ja osoittaa sen olevan pedagogisesti merkittävää (ks. myös 
Taleghani-Nikazm 2008). Hän linkittää ikonisen, puhetta korvaavan eleen ja vastauksen semanttisen sisällön yhteen sekä etualaistaa oppitunnin agendan kannalta keskeisen tiedon antamalla vihjeen vastauksesta. Myös tässä esimerkissä ele auttaa oppilaita kysymyksen ymmärtämisessä ja näin osaltaan tarjoaa lisää osallistumisen mahdollisuuksia, kun kysymyksen ymmärtäminen ja siihen vastaaminen eivät välttämättä riipu kielitaidon tasosta.

Edellä analysoimieni esimerkkien valossa kehollisella toiminnalla on monenlaisia funktioita opetuskeskustelussa. Vaikka keskeisenä tarkastelun kohteena ovat olleet opettajan esittämät kysymykset ja niihin linkittyvät eleet, esimerkit osoittavat, kuinka kokonaistavaltaisia ja vuorovaikutusta läpileikkaavia erilaiset keholliset toiminnot ovat. Opettajan eleet linkittyvät kysymysten semanttiseen sisältöön ja auttavat oppilaita ymmärtämään kysymyksiä. Eleet tukevat sekä opettajaa että oppilasta. Opettaja voi eleillä korvata tai tukea puhetta, jolloin se, ymmärtääkö oppilas opettajan kysymyksen, ei jää kiinni pelkästään suullisesta ilmaisusta. Tämä voi tarjota useammalle oppilaalle mahdollisuuden osallistua vuorovaikutukseen. Vastauksen tuottaminen eleenä voi olla myös oppilaalle keino osallistua ja näyttää osaamista.

\subsection{Opettaja sanallistaa oppilaan kehollisesti tuottaman vuoron}

Analyysiluvun toisessa osassa tarkastelen, miten opettaja sanallistaa oppilaiden kehollisesti tuottamia vuoroja (ks. tässä artikkelissa myös esimerkit 1 ja 3) ja miten oppilaat käyttävät kehollista toimintaa vastausvuoroissaan. Sanallistamisella tarkoitan tässä artikkelissa sitä, miten vuorovaikutuksen osallistujat muuttavat kehollisen toiminnan sanalliseen muotoon. Esimerkissä 5 opettaja ja oppilaat ovat edellä keskustelleet sydämen toiminnasta. Tässä esimerkissä opettaja sanallistaa oppilaan vuoron, jonka tämä tuottaa opettajan esittämän kysymyksen jälkeen.

(5) Sit kuolee.

01 OPE mịtä sit tạpahtuu jọs sydän pysähtyy?

\{KATSOO ENSIN ROLANIIN, SITTEN EETUUN

02 EET iy:y.

\section{\{TIPAUTTAA PÄÄNSÄ PÖYDÄLLE}

03 OPE mmmh sịt küolee.

\{SIIRTÄÄ KATSEENSA EETUSTA MUIHIN OPPILAISIIN

$04(1.5)$

05 OPE sịt pitää antaa semmosia (1.3) sähköshokkeja (.)

\{LAITTAA KÄTENSÄ NYRKKIIN, NOSTAA NE RINTANSA ETEEN

JA LIIKUTTAA NIITÄ EDESTAKAISIN RINTANSA PÄÄLLÄ

06 eiks nii? 


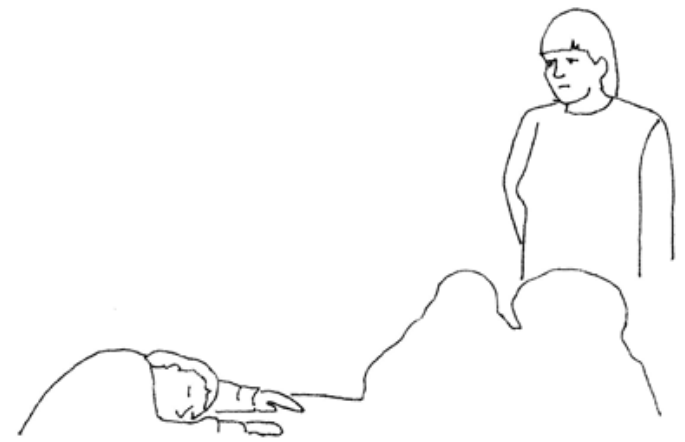

Piirroskuva 3

Katkelma on oiva esimerkki siitä, kuinka monitahoista opettajan ja oppilaan kehollinen toiminta voi lyhyessäkin katkelmassa olla. Opettaja aloittaa esittämällä hakukysymyksen mitä sit tapahtuu jos sydän pysähtyy (r. 01). Hän ei eksplisiittisesti, esimerkiksi nimeämällä, osoita vuoroa kenellekään oppilaista. Kysymyksensä aikana hän kuitenkin kohdistaa katseensa ensin Rolaniin ja sitten Eetuun. Eetu ottaakin vastausvuoron (r. 02), jonka aikana hän tuottaa äännähdyksen ja tipauttaa päänsä pöytää vasten (ks. piirroskuva 3). Eetu tuottaa tässä ikonisen eleen, jolla hän korvaa sanallisen ilmauksen.

Opettajan seuraavaan vuoroon $\mathrm{mmh}$ sit kuolee (r. 03) sulautuu monia toimintoja. Ensinnäkin se toimii kolmiosaisen opetussyklin kolmannen position arvioivana vuorona, jolla opettaja hyväksyy Eetun eleenä tuottaman vastauksen. Toiseksi hän sanallistaa Eetun kehollisen toiminnan (ks. piirroskuva 3). Opettajan vuoroa seuraa tauko, jonka aikana hän siirtää katseensa Eetusta takaisin kaikkiin oppilaisiin. Hän jatkaa selittävällä vuorolla sit pitää antaa semmosia sähköshokkeja (r. 05) ja samanaikaisesti elehtii käsillään elvyttämistä. Opettajan ikoninen ele tukee sanallista ilmausta ja helpottaa sen ymmärtämistä.

Kiinnostavaa tässä esimerkissä on se, miten opettaja suuntautuu oppilaan kehollisesti tuottamaan vastaukseen. Kuten jo luvun 4.1 esimerkissä 3 huomattiin, opettaja ei osoita eleenä tuotettua vastausta (r. 02) riittämättömäksi, vaikka puheena tuotettu vastaus puuttuukin. Opettajan evaluoiva vuoro osoittaa, että hän käsittelee eleenä tuotettua opetussyklin toisen position vuoroa vastauksena kysymykseensä ja suuntautuu siihen samanarvoisesti kuin puheena tuotettuun vastaukseen. Oppilaan kehollinen toiminta vastauksena antaa jälleen oppilaalle mahdollisuuden osallistua ja näyttää osaamista, ja opettajalle se antaa mahdollisuuden sanallistaa oppilaan kehollinen toiminta. Sanallistaminen tarjoaa siten myös tilan kielen oppimiselle. Opettajan tehtäväksi jää oppilaan vastauksen muovaaminen kielen oppimista palvelevaksi toiminnaksi (ks. Walsh 2011). 
Edellä esittelemässäni esimerkissä opettaja teki suoraviivaisen tulkinnan siitä, millaisen vastauksen oppilas antoi kehollisella toiminnallaan. Seuraavassa esimerkissä opettaja tarjoaa oppilaalle vuoron korjausmahdollisuuden. Keskustelunaiheena on edelleen sydämen toiminta.

(6) Kun pelästyy.

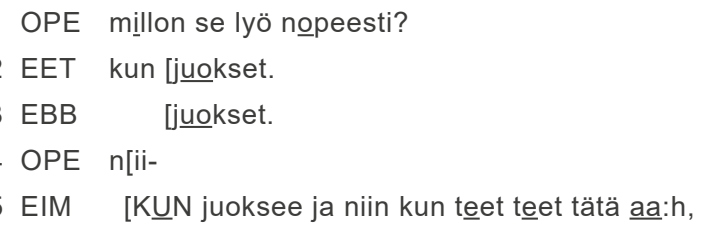

Esimerkki alkaa, kun opettaja esittää kysymyksen siitä, milloin sydän lyö nopeasti (r. 01). Eetu ja Ebba ottavat lähes samanaikaisesti vuoron ja vastaavat opettajan kysymykseen päällekkäispuhuntana: juokset (r. 02 ja r. 03). Opettaja hyväksyy (r. 04) Eetun ja Ebban vastaukset dialogipartikkelilla nii, mutta vuoro jää kesken, kun oppilaista myös Eimar ottaa vastausvuoron (r. 05).

Eimarin vuoronalkuinen kun-konjunktio on lausuttu selvästi muuta puhetta kovemmalla äänellä, mikä voi implikoida Eimarin halua vastata kysymykseen, vaikka Eetu ja Ebba ovat jo antaneet siihen vastauksen. Hän toistaa Eetun ja Ebban vastauksen kun juoksee, mutta jatkaa vielä vuoroaan ja lisää siihen kehollisen toiminnan: kun juoksee ja niin kun teet teet tätä aah (r. 05). Vuoron lopussa Eimar nostaa kädet eteensä, haukkoo henkeään ja nojautuu tuolinsa selkänojaa vasten. Opettajan tulkinta siitä, mitä Eimar ilmaisee eleellä, seuraa heti Eimarin vuoroa: kun pelästyy vai (r. 06).

Kiinnostavaa tässä esimerkissä on se, että opettaja tuottaa kehollisen toiminnan sanallistamisen perään rinnastuskonjunktion vai, mikä antaa Eimarille mahdollisuuden korjata opettajan kenties väärä tulkinta tämän eleestä. Lilja (2010) on tarkastellut kielenoppijoiden vuorovaikutuksessa ymmärrysehdokkaita eli päätelmiä siitä, mitä puhuja on tarkoittanut vuorossaan. Liljan aineistossa tyypillisen ymmärrysehdokkaan rakenteeseen kuuluu partikkeliosio alussa, ymmärrysehdokkaan ydin eli ymmärrysehdokasosio (kun pelästyy) ja sitä seuraava partikkeliosio lopussa (vai). Yksi ymmärrysehdokkaan funktioista on edeltävissä vuoroissa sanomatta jääneen asian tarkentaminen. (Lilja 2010: 138-141.) Tässä esimerkissä opettaja sanal- 
listamalla tarkentaa Eimarin vastauksen. Partikkeliosiota seuraa lyhyt tauko ennen kuin hän hyväksyy vastauksen partikkelivuorolla nii joo (r. 06). Koska Eimar ei esitä opettajan tulkinnan torjuvaa vuoroa, opettajan tulkinta Eimarin kehollisesta toiminnasta säilyy.

Mielenkiintoista on yhtäältä se, että Eimar ei tuota projisoitua ymmärrysehdokkaan vahvistusta opettajan vuoron jälkeen (ks. Sorjonen 2001: 58; Lilja 2010: 141), ja toisaalta myös se, että opettaja tuottaa Eimarin vastauksen hyväksyvän partikkelivuoron nopeasti ymmärrysehdokkaan jälkeen ja esittää sen jälkeen aihetta vaihtavan uuden kysymyksen (r. 8). Tilanteen sosiaalisen järjestäytymisen kannalta opettaja on tiedollinen auktoriteetti (Kurhila 2001; Kleemola 2007). Eimar voi suuntautua instituution määrittämiin rooleihin ja hyväksyä opettajan tulkinnan tälle vastaamatta.

Erityisesti uutta kieltä oppivat puhujat kompensoivat leksikaalista tietämättömyyttä kehollisella toiminnalla, kuten eleillä ja liikkeellä. Jotta leksikaalinen aines voidaan ikään kuin aidosti korvata, kehollisen toiminnan ja puheen täytyy linkittyä toisiinsa. (Gullberg 2008; ks. myös Seo 2011.) Tämän artikkelin esimerkkikatkelmissa oppitunnin aiheena on ihmisen biologia; kieli ja keho liittyvät siinä saumattomasti yhteen. Oppitunneilla, joilla aiheet ovat abstraktimpia, linkki kielen ja kehollisuuden välillä ei välttämättä ole yhtä ilmeinen.

Toisen analyysiosan viimeinen esimerkki on oppitunnin alusta. Opettaja ja oppilaat ovat juuri asettuneet pöydän ääreen istumaan. Opettaja esittää oppilaille kysymyksiä sydämen toiminnasta.

(7) Sydämen koko.

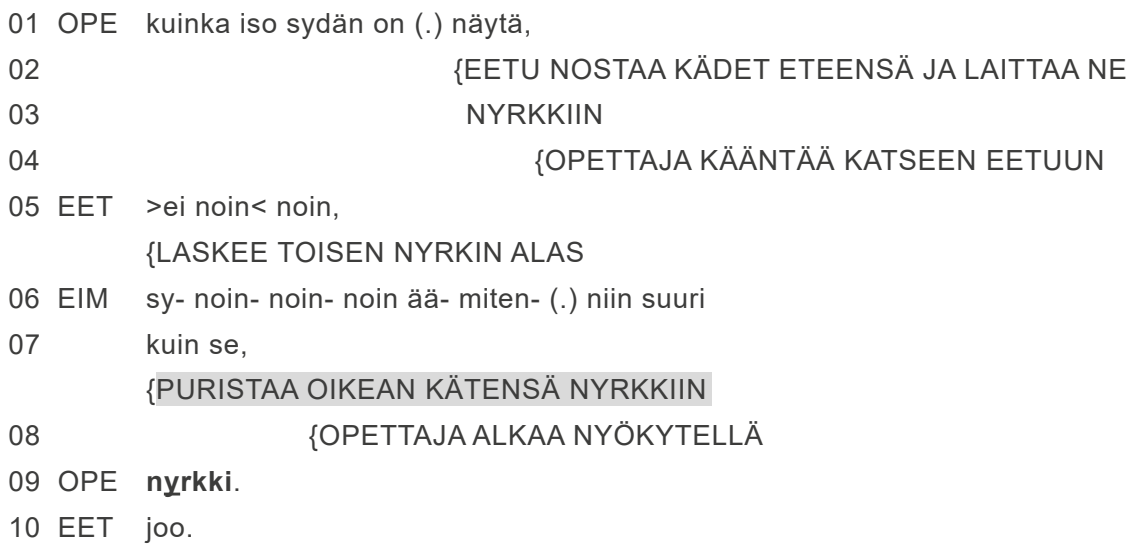



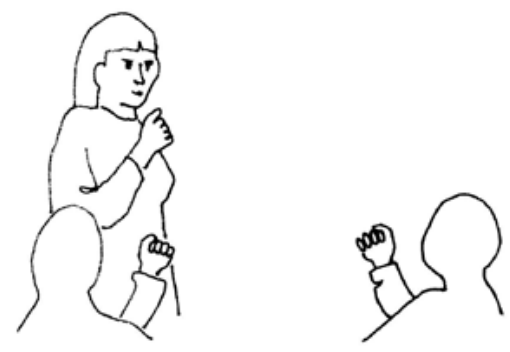

Piirroskuva 4

Aluksi opettaja esittää kysymyksen kuinka iso sydän on (r. 01). Lyhyen tauon jälkeen hän tuottaa ohjailevan lausuman näytä, jolla hän kehottaa oppilaita tuottamaan vastauksen kehollisena toimintana (direktiivien funktioista ks. ISK 2004: § 1645). Eetu nostaa kehotuksen aikana kätensä nyrkkiin (r. 02-03) ja opettaja kääntää katseensa Eetuun (r. 04).

Eetu tuottaa seuraavaksi itsekorjauksen (r. 05), jolla hän itse asiassa korjaa kehollisena toimintana tuottamaansa vastausta laskemalla toisen nyrkkinsä alas: ei noin noin. Myös Eimar ottaa vastausvuoron (r. 06-07) ja puristaa kätensä nyrkkiin. Vuorossaan hän empii, venyttää äänteitä ja tekee runsaasti itsekorjauksia. Goodwinin ja Goodwinin (1986: 55) mukaan tällaiset piirteet puheessa osoittavat, että kielentuottamisessa on ongelmia. Opettaja kääntää katseensa Eimariin lähes heti, kun tämä alkaa puhua. Eimarin vuoron aikana opettaja nyökyttelee ja sen jälkeen sanallistaa tämän eleen ja tarjoaa siitä päätelmän: nyrkki (r. 09, ks. piirroskuva 4). Hän laittaa myös oman kätensä nyrkkiin.

Opettaja odottaa ensin, että Eimar saisi itse ratkaistua sanahaun, ennen kuin alkaa nyökytellä vastauksen hyväksymisen merkiksi. Odottaminen voi johtua myös siitä, että opettaja osoittaa odottavansa lisätietoa (ks. Pomerantz 1984). Lisäksi hän antaa Eimarille aikaa sanoa vuoronsa loppuun keskeytyksettä. Huomiota kiinnittää se, että Eetu, joka on yhtenä vastausvuoron ottaneista mukana tilanteisessa osallistumiskehikossa, hyväksyy opettajan tarjoaman päätelmän Eimarin sijasta (r. 10). Eimar ei katkelman jälkeen ilmaise erimielisyyttä, mikä voi implikoida sitä, että Eimar hyväksyy opettajan päätelmän.

Kehollisella toiminnalla on jälleen monenlaisia funktioita: Ensinnäkin se antaa oppilaalle mahdollisuuden vastata opettajan esittämään kysymykseen ja osallistua vuorovaikutukseen, vaikka oppilaan suullinen kielitaito ei vielä siihen riittäisikään. Toiseksi juuri kehollisen toiminnan avulla oppilaan vastaus luo tilan kielen oppimiselle. Kun oppilas tuottaa opetussyklin toisen position vastausvuoron kehollisena toimintana, opettaja voi sanallistaa toiminnan ja tällä tavoin edesauttaa kielenop- 
pimista. Walshin (2011:121-138) mukaan kehollinen toiminta on yksi luokkahuonevuorovaikutuksessa kielen oppimista avustava ja merkityksiä välittävä resurssi, jota voivat luokkahuoneessa käyttää hyväksi sekä opettaja että oppilas. Myös Eskildsenin ja Wagnerin (2013) mukaan uutta kieltä voi oppia ja opettaa eleillä, jotka syntyvät jaetusta vuorovaikutuksellisesta tilasta.

\section{Kokoavaa pohdintaa}

Tässä artikkelissa olen tarkastellut, millä tavoin kehollisuus tukee vuorovaikutusta sekä siihen osallistumista valmistavassa luokkahuoneessa. Analyysin lähtökohtana ovat olleet opettajan kysymysaloitteet ja niihin kuuluva kehollinen viestintä sekä se, miten opettaja sanallistaa oppilaiden vastausvuoroihin liittyvää kehollisuutta. Olen siis analysoinut myös oppilaiden kehollista toimintaa vastausvuoroissa. Analyysin keskiössä ovat olleet eleet ja niiden linkittyminen puheena tuotettuihin ilmauksiin. Sekventiaalisena jäsennystapana hyödynsin kolmiosaista opetussykliä, joka on konventionaalistunut perusrakenne luokkahuonevuorovaikutuksen tarkasteluun (ks. esim. Tainio 2007; Heinonen 2017).

Analysoimissani katkelmissa kehollinen toiminta näyttäytyy ensinnäkin pedagogisena apuvälineenä, joka tukee opetuskeskustelua monin tavoin (ks. myös Lazaraton 2004; Taleghani-Nikazm 2008). Kun opettaja kolmiosaisen opetussyklin ensimmäisessä positiossa täydentää oppilaille esittämäänsä kysymystä elein, hän voi ohjata oppilaiden huomion kysymyksen ymmärtämisen kannalta keskeiseen sisältöön. Vaikka on hankala todentaa, millainen vuorovaikutus palvelee tilanteen institutionaalisia päämääriä ja kielenoppimista parhaiten (ks. myös TaleghaniNikazm 2008), voi kehollinen toiminta helpottaa tilanteen ymmärtämistä ja mahdollistaa siihen osallistumisen kielitaidon tasosta huolimatta (ks. myös Tai \& Brandt 2018). Kun sanaselityksen tuottaa kehollisesti, suullisen selittämisen tarve vähenee (Lazaraton 2004: 100).

Vastauksen tuottaminen kehollisesti näyttäytyy analyysissani oppilaiden $\mathrm{yh}$ denlaisena keinona osallistua vuorovaikutukseen ja näin näyttää osaamista. Kun oppilas tuottaa vastauksen sanallista ilmaisua korvaavana kehollisena toimintana, opettajalla puolestaan on mahdollisuus sanallistaa toiminta ja näin sekä toteuttaa kielenopetusta että edesauttaa kielenoppimista. Vaikka aina ei ole täysin selvää, osuuko opettajan tulkinta oikeaan tai johtuuko oppilaan kehollisesti tuotettu vastaus kielitaidon puutteesta, kehollisen toiminnan sanallistaminen joka tapauksessa vie vuorovaikutusta eteenpäin ja antaa tilaa intersubjektiivisuuden toteutumiselle, mikä on myös edellytys sille, että puhujat voivat toimia yhdessä (ks. Sorjonen 2010: 86). Sanallistaminen voi edesauttaa vuorovaikutusta myös siinä suhteessa, että se on vähemmän monitulkintaista kuin elehtiminen. 
Onnistunut vuorovaikutus perustuu vuorovaikutuksen osallistujien väliselle yhteistyölle, mikä on perustavanlaatuista kaikessa sosiaalisessa toiminnassa. Vuorovaikutuksen osallistujat esimerkiksi muotoilevat puheensa lausumien ja vuorojen sisäistä rakennetta vuorovaikutustilanteessa niin, että vuoro sopii erilaisille vastaanottajille. (Goodwin 1981: 167-173.) Tämä toteutuu myös valmistavassa opetuksessa: vuorovaikutus on resurssi, jolla voidaan edistää kielenoppimista. Opettaja ja oppilaat käyttävät kieltä niin, että he muokkaavat sitä vastaanottajalle sopivaksi (Walsh 2011).

Kehollinen toiminta laajentaa osallistujuuden muotoja: opettajalle se voi olla yhdenlainen tapa tarjota mahdollisimman monelle vastaajan rooli, kun taas oppilas voi hyödyntää sitä keinona tuottaa vastausvuoro. Osallistuminen opetuskeskusteluun ei tällöin riipu kielitaidon tasosta. Kehollinen toiminta mahdollistaa oppilaan osallistumisen vuorovaikutukseen ja samalla tarjoaa tilaisuuden kielen oppimiselle ja opettamiselle. Kiehtovaa on se, että esimerkkikatkelmien valossa kehollinen toiminta näyttäytyy vuorovaikutukseen osallistumisen tukijana ja mahdollistajana riippumatta siitä, korvaako vai tukeeko se sanallista ilmausta.

Edellä mainittuun liittyy osaltaan se, miten opettaja ja oppilaat suhtautuvat keholliseen toimintaan osana luokkahuoneen vuorovaikutusta. Analyysini perusteella vaikuttaa siltä, että kehollisena toimintana tuotettuja vuoroja pidetään yhtä merkittävinä ja vuorovaikutusta jäsentävinä kuin vuoroja, jotka opettaja tai oppilas tuottavat puheena. Kun oppilas tuotti opetussyklin toisen position vastausvuoron kehollisena toimintana, opettaja suuntautui siihen vastauksena kysymykseensä ja hyväksyi sen osaksi vuorovaikutusta.

Opettaja pyrkii kehollisella toiminnalla auttamaan oppilaita eteenpäin (Tellier 2010: 2). Analyysissani havaitsin, että kehollinen toiminta on usein kompleksista ja monimuotoista ja että se liittyy keskeisiin toimintoihin luokkahuoneessa: opettamiseen, oppimiseen ja vuorovaikutukseen osallistumiseen. Lisäksi analysoimieni esimerkkien valossa puhe ja kehollinen toiminta linkittyvät läheisesti toisiinsa. Oppilaille kehollinen toiminta tarjoaa erityisesti mahdollisuuden osallistua ja näyttää osaamista. Opettaja puolestaan hyödyntää sitä edistämään oppitunnin tavoitetta eli opettamista ja oppimista, mihin luokkahuoneessa liittyy saumattomasti myös kielen oppimisen mahdollisuus jokaisessa vuorovaikutustilanteessa.

Analyysissani on joitakin rajoitteita, jotka on hyvä nostaa esille. Laadullisen, yhden luokkahuoneen vuorovaikutusta tarkastelevan tutkimuksen perusteella ei voi tehdä päätelmiä siitä, missä määrin kehollinen toiminta on hyödyllistä kielenoppimisen tai ymmärtämisen kannalta (vrt. Taleghani-Nikazm 2008). Multimodaalinen keskusteluanalyysi tarjoaa ikkunan vuorovaikutuskäytänteiden kuvaamiseen, mutta ei niinkään oppimisprosessien todentamiseen. Huomionarvoista on lisäksi analysoimieni oppituntien aihe eli ihmisen kehon toiminta. Aiheena tämä tarjoaa oivallisen sisällön tarkastella kehollista toimintaa, mutta eri oppiaineet ja aiheet voivat olla eri 
suhteessa toisiinsa siinä, missä määrin kehollisuutta hyödynnetään vuorovaikutuksellisena ja pedagogisena resurssina.

Tämä artikkeli jatkaa osaltaan keskustelua osallistumisen mahdollisuuksista ja multimodaalisten keinojen hyödyntämisestä uutta kieltä oppivien luokkahuonevuorovaikutuksessa (ks. esim. Eskildsen \& Wagner 2013; Routarinne \& Ahlholm 2021) sekä valaisee kehollista toimintaa vuorovaikutusta tukevana keinona valmistavassa opetuksessa sekä oppilaan että opettajan toiminnasta käsin. Jatkotutkimuksen kannalta merkittävää olisi tutkia, miten opettaja ja oppilaat itse suhtautuvat keholliseen toimintaan osana opetuskeskustelua. Kiinnostavaa olisi tarkastella esimerkiksi sitä, miten tietoista eleiden käyttäminen osana opetuskeskustelua valmistavassa opetuksessa on. Tämä tutkimus voi osaltaan tarjota keskustelunavauksia opettajankoulutukseen ja vuorovaikutuskäytänteiden näkyväksi tekemiseen valmistavassa opetuksessa.

\section{Kirjallisuus}

Ahlholm, M. 2016. Englanti venäjänkielisen alakoululaisen suomen kielen oppimisen tukena. AFinLA-E: Soveltavan kielitieteen tutkimuksia, (8), 93-112.

Ahlholm, M. \& Lankinen, N. (toim.) 2021. Vastaantulo - Meeting in the middle 2017-19. Valmistavaa opetusta tutkivan ja kehittävän hankkeen blogi. Helsingin yliopisto, Opetus- ja kulttuuriministeriö. https://blogs.helsinki.fi/vastaantulo/tutkimus [Luettu 5.6.2021]

Eskildsen, S.W. \& J. Wagner 2013. Recurring and shared gestures in the L2 classroom: resources for teaching and learning. European Journal of Applied Linguistic 1 (1), 139-161. https://doi.org/10.1515/eujal-2013-0007.

Eskildsen, S.W. \& J. Wagner 2015. Embodied L2 construction learning. Language Learning 65 (2), 268-297. https://doi.org/10.1111/lang.12106.

Filipi, A. \& N. Markee 2018. Conversation analysis and language alternation: capturing transitions in the classroom. Amsterdam: John Benjamins Publishing Company.

Goodwin, C. 1981: Conversational Organization. Interaction Between Speakers and Hearers. New York: Academic Press.

Goodwin, C. 2017. Co-operative action. New York, NY: Cambridge University Press.

Goodwin, M. J. \& C. Goodwin 1986. Gesture and coparticipation in the activity of searching for a word. Semiotica, 62, 51-75. https://doi.org/10.1515/semi.1986.62.1-2.51.

Gullberg, M. 2008. Gestures and second language acquisition. Teoksessa P. Robinson \& N.C. Ellis (toim.) Handbook of cognitive linguistics and second language acquisition. New York ja Lontoo: Routledge, 276-305.

Gustafsson, M. 2014: "Opettaja, saaks sanoa?" - pitkittäistutkimus suomi toisena kielenä -oppilaiden oma-aloitteisesta suomen kielen käytöstä alakoulun perusopetukseen valmistavassa opetuksessa. Pro gradu -tutkielma. Helsingin yliopisto.

Heinonen, P. 2017. Evaluointi opettajan vuorovaikutustoimintana: osallistujuuden ulottuvuudet luokkahuoneessa. Helsinki: Helsingin yliopisto.

Helkiö, N. 2019. Kehollinen toiminta opettajan vuorovaikutusresurssina kakkoskielisessä luokkahuonevuorovaikutuksessa. Pro gradu -tutkielma. Helsingin yliopisto. 
Heritage, J. 1996 [1984]. Harold Garfinkel ja etnometodologia. Suom. I. Arminen, O. Paloposki, A. Peräkylä, S. Vehviläinen \& S. Veijola. Helsinki: Gaudeamus.

Heritage, J. 2005. Conversation analysis and institutional talk. Teoksessa K. L. Fitch \& R.E. Sanders (toim.) Handbook of language and social interaction. Mahwah: Psychology Press, 103-147.

Hoey, E. M. \& K.H. Kendrick 2018. Conversation analysis. Teoksessa A.M.B. de Groot \& P. Hagoort (toim.) Research methods in psycholinguistics and the neurobiology of language: a practical guide. Hoboken: Wiley, Blackwell, 151-174.

ISK = A. Hakulinen, M. Vilkuna, R. Korhonen, V. Koivisto, T. R. Heinonen \& I. Alho 2004. Iso suomen kielioppi. Helsinki: SKS.

Jones, R. \& J. Thornborrow 2004. Floors, talk and the organization of classroom activities. Languace in Society, 33, 399-423. https://doi.org/10.1017/S0047404504043040.

Karvonen, K. 2007. Puheenvuoro oppilaalle. Teoksessa L. Tainio (toim.) Vuorovaikutusta luokkahuoneessa: näkökulmana keskustelunanalyysi. Helsinki: Gaudeamus, 119-138.

Kendon, A. 1980. Gesticulation and speech: two aspects of the process of utterance. Teoksessa M.R. Key (toim.) The Relationship of verbal and nonverbal communication. The Hague: Mouton \& Co, 207-227.

Kendon, A. 2004. Gesture: visible action as utterance. Cambridge: Cambridge University Press.

Keravuori, K. 1988. Ymmärränkö tarkoitukses: tutkimus diskurssirooleista ja funktioista. Helsinki: SKS.

Kleemola, S. 2007. Opettajan kysymykset oppitunnilla. Teoksessa L. Tainio (toim.) Vuorovaikutusta luokkahuoneessa: näkökulmana keskustelunanalyysi. Helsinki: Gaudeamus, 61-89.

Kurhila, S. 2001. Asiantuntijuuden kerrostumista. Syntyperäiset ja ei-syntyperäiset suomenpuhujat virkailijoina ja asiakkaina. Teoksessa J. Ruusuvuori, M. Haakana Haakana \& L. Raevaara (toim.) Instititutionaalinen vuorovaikutus. Keskustelunanalyyttisia tutkimuksia. Helsinki: Suomalaisen Kirjallisuuden Seura, 178-195.

Kurhila, S. \& Lehtimaja, I. 2019. Ammattikielen tilanteisuus kielenoppimisen haasteena - esimerkkinä hoitoala. Teoksessa L. Kotilainen, S. Kurhila \& J. Kalliokoski (toim.) Kielenoppiminen luokan ulkopuolella. Helsinki: Suomalaisen Kirjallisuuden Seura, 143-171.

Kääntä, L. 2011. Katse, nyökkäys ja osoittava ele opettajan vuoronannoissa luokkahuonevuorovaikutuksessa. Teoksessa L. Kääntä \& P. Haddington (toim.) Kieli, keho ja vuorovaikutus. Multimodaalinen näkökulma sosiaaliseen toimintaan. Suomalaisen Kirjallisuuden Seuran Toimituksia 1337, 122-151.

Kääntä, L. 2021. Multimodal perspective into teachers' definitional practices: comparing subject-specific language in physics and history lessons. Teoksessa Kunitz, S., N. Markee \& O. Sert (toim.) Classroom-based conversation analytic research: theoretical and applied perspectives on pedagogy. Educational Linguistics, 46. Cham: Springer International Publishing, 197-223. https://doi.org/10.1007/978-3-030-52193-6_10.

Kääntä, L. \& P. Haddington 2011. Johdatus multimodaaliseen vuorovaikutukseen. Teoksessa L. Kääntä \& P. Haddington (toim.) Kieli, keho ja vuorovaikutus. Multimodaalinen näkökulma sosiaaliseen toimintaan. Suomalaisen Kirjallisuuden Seuran Toimituksia $1337,11-48$.

Lazaraton, A. 2004. Gestures and speech in the vocabulary explanations of one ESL teacher: a microanalytic inquiry. Language Learning, 54(1), 79-117. https://doi.org/10.1111/ j.1467-9922.2004.00249.x. 
Lehtimaja, I. 2012. Puheen suuntia luokkahuoneessa: oppilaat osallistujina yläkoulun suomi toisena kielenä-tunnilla. Helsinki: Helsingin yliopisto. https://doi.org/10.1017/ S004740450332202X.

Lilja, N. 2010. Ongelmista oppimiseen. Toisen aloittamat korjausjaksot kakkoskielisessä keskustelussa. Jyväskylä Studies in Humanities 146. Jyväskylä: Jyväskylän yliopisto.

Lilja, N. \& A. Piirainen-Marsh 2019. Connecting the language classroom and the wild: reenactments of language use experiences. Applied Linguistics, 40 (4), 594-623. https:// doi:10.1093/applin/amx045.

Lindholm, C., M. Stevanovic \& A. Peräkylä 2016. Johdanto. Teoksessa M. Stevanovic \& C. Lindholm, (toim.) Keskustelunanalyysi. Kuinka tutkia sosiaalista toimintaa ja vuorovaikutusta. Tampere: Vastapaino, 9-26.

Markee, N. 2005. The organization of off-task talk in second language classrooms. Teoksessa K. Richards \& P. Seedhouse (toim.) Applying conversation analysis. London : Palgrave Macmillan, 197-213.

Markee, N. 2015. The handbook of classroom discourse and interaction. Hoboken, N.J. : Wiley.

McNeill, D. 1992. Hand and mind: what gestures reveal about thought. Chicago: University of Chicago Press.

Mortensen, K. 2008. Selecting next speaker in the second language classroom: how to find a willing next speaker in planned activities. Journal of Applied Linguistics 5(1), 55-79. https://doi.org/10.1558/japl.v5i1.55.

OPH 2015. Perusopetukseen valmistavan opetuksen opetussuunnitelman perusteet. Helsinki: Opetushallitus.

Pallotti, L. \& J. Wagner 2011. L2 learning as social practice: conversation-analytic perspectives. Honolulu: National Foreign Language Resource Center, University of Hawai'i.

Peräkylä, A. 1997. Institutionaalinen keskustelu. Teoksessa L. Tainio (toim.) Keskustelunanalyysin perusteet. Tampere: Vastapaino, 177-203.

Pomerantz, A. 1984. Pursuing a response. Teoksessa M. Atkinson, \& J. Heritage (toim.) Structures of social action: studies in conversation analysis. Cambridge ja New York: Cambridge University Press, 152-163.

Raevaara, L. 2016. Toimintajaksojen rakenteet. Teoksessa M. Stevanovic, \& C. Lindholm (toim.) Keskustelunanalyysi. Kuinka tutkia sosiaalista toimintaa ja vuorovaikutusta. Tampere: Vastapaino, 143-161.

Routarinne, S. \& M. Ahlholm 2021: Developing requests in multilingual classroom interaction. A case of second language development in middle childhood. Applied Linguistics 42, 765-790. https://doi:10.1093/applin/amaa048.

Ruusuvuori, J. 2016. Katse. Teoksessa M. Stevanovic, \& C. Lindholm (toim.) Keskustelunanalyysi. Kuinka tutkia sosiaalista toimintaa ja vuorovaikutusta. Tampere: Vastapaino, 47-62.

Savijärvi, M. 2019. Yhdessä oppiminen teatteriharjoituksissa - fokuksessa sanahaut. Teoksessa L. Kotilainen, S. Kurhila \& J. Kalliokoski (toim.) Kielenoppiminen luokan ulkopuolella. Helsinki: Suomalaisen Kirjallisuuden Seura, 88-113.

Seedhouse, P. 2004. The interactional architecture of the language classroom: a conversation analysis perspective. Malden: Blackwell Publishing.

Seo, M.S. 2011. Talk, body, and material objects as coordinated interactional resources. Teoksessa L. Pallotti \& J. Wagner (toim.) L2 earning as social practice: conversationanalytic perspectives. Honolulu: National Foreign Language Resource Center, University of Hawai'i, 108-134. 
Seyfeddinipur, M. \& M. Gullberg 2014. From gesture in conversation to visible action as utterance. Teoksessa M. Seyfeddinipur \& M. Gullberg (toim.) From gesture in conversation to visible action as Utterance. Essays in honor of Adam Kendon. Amsterdam: John Benjamins Publishing Company, 1-12.

Sert, O. 2015. Social action and L2 classroom discourse. Edinburgh: Edinburgh University Press. Sinclair, J. \& R.M. Coulthard 1975. Towards an analysis of discourse: the English used by teachers and pupils. London: Oxford University Press.

Sorjonen, M.-L. 2001. Responding in conversation. A study of response particles in Finnish. Amsterdam: John Benjamins Publishing Co.

Sorjonen, M.-L. 2010. Kieli ja yhteisymmärrys. Virittäjä, 115(1), 85-92. https://journal.fi/ virittaja/article/view/4036.

Stivers, T. \& J. Sidnell 2005. Introduction: multimodal interaction. Semiotica, 156(1), 1-20.

Tai, K. W. H. \& A. Brandt 2018. Creating an imaginary context: teacher's use of embodied enactments in addressing learner initiatives in a beginner-level adult ESOL classroom. Classroom Discourse, 9:3, 244-266. https://doi.org/10.1080/19463014.201 8.1496345.

Tai, K. W. H. \& N. Khabbazbashi 2019. Vocabulary explanations in beginning-level adult ESOL classroom interactions: a conversation analysis perspective. Linguistics and Education, 52, 61-77. https://doi.org/10.1016/j.linged.2019.06.006.

Tainio, L. 2005. Luokkahuoneen vuorottelujäsennyksen rikkomukset. Teoksessa L. Kuure, E. Kärkkäinen \& M. Saarenkunnas (toim.) Kieli ja sosiaalinen toiminta. AFinLAn vuosikirja 2005. Suomen soveltavan kielitieteen yhdistyksen julkaisuja 63. Jyväskylä: Suomen soveltavan kielitieteen yhdistys AFinLA, 179-192.

Tainio, L. 2007. Miten tutkia luokkahuoneen vuorovaikutusta keskustelunanalyysin keinoin? Teoksessa L. Tainio (toim.) Vuorovaikutusta luokkahuoneessa: näkökulmana keskustelunanalyysi. Helsinki: Gaudeamus, 15-58.

Taleghani-Nikazm, C. 2008. Gestures in foreign language classrooms: an empirical analysis of their organization and function. Teoksessa M. Bowles, R. Foote, S. Perpiñán \& R. Bhatt (toim.) Selected proceedings of the 2007 Second Language Research Forum. Somerville, MA: Cascadilla Proceedings Project, 229-238.

Tellier, M. 2010. The effect of gestures on second language memorisation by young children. Teoksessa M. Gullberg, \& K. de Bot (toim.) Gestures in language development. Amsterdam: J. Benjamins, 75-91.

Walsh, S. 2011. Exploring classroom discourse: language in action. London: Routledge. 


\section{Liite: litterointimerkit}

$\begin{array}{ll}{[]} & \text { päällekkäispuhunta } \\ (.) & 0.2 \text { sekuntia lyhyempi tauko } \\ (1.5) & \text { tauon kesto sekunteina } \\ , & \text { tasainen intonaatio } \\ \cdot & \text { laskeva intonaatio } \\ ? & \text { nouseva intonaatio } \\ \text { sana } & \text { äänteen painottaminen } \\ \text { sana:: } & \text { äänteen venytys } \\ \text { sa- } & \text { kesken jäänyt sana } \\ £ \text { sana£ } & \text { hymyillen puhuttu sana } \\ >\text { sana< } & \text { ympäröivää puhetta nopeampi puhe } \\ \text { SAna } & \text { painotus / voimakkaammin puhuttu sana } \\ (--) & \text { puhe, josta ei saa selvää } \\ \uparrow & \text { seuraava sana lausuttu ympäröivää puhetta korkeammalta } \\ = & \text { kaksi sanaa liittyy tauotta toisiinsa }\end{array}$

